\title{
THE EFFECT OF ARTIFICIAL FEVER AND SPECIFIC ANTISERUM ON THE ORGANISMS PRESENT IN CASES OF TYPE III PNEUMOCOCCUS MENINGITIS
}

\author{
BY MORRIS F. SHAFFER, ${ }^{1}$ JOHN F. ENDERS AND JAMES WILSON \\ (From the Department of Bacteriology and Immunology and the Department of Pediatrics of \\ the Harvard University Medical School, Boston)
}

(Received for publication December 17, 1937)

One of the very serious problems encountered in pediatric practice is that of the treatment of pneumococcal meningitis. The significance of this statement is emphasized by an examination of the records and statistics concerning the cases of meningitis observed over a ten-year period in a hospital such as the Children's Hospital at Boston. During 1926 to 1936 there occurred 114 cases of meningococcus meningitis with 41 deaths and 73 recoveries, 96 cases of $H$. influenzae meningitis with 92 deaths and 4 recoveries, and 74 cases of pneumococcus meningitis with 73 deaths and 1 recovery. Of these 284 cases, 26 per cent were attributable to pneumococcus infection, and the mortality in this group was over 98 per cent. An analysis of these pneumococcal infections showed that the distribution according to type was as follows:

\begin{tabular}{c|c|c|c}
\hline Type & $\begin{array}{c}\text { Number } \\
\text { of } \\
\text { cases }\end{array}$ & Type & $\begin{array}{c}\text { Number } \\
\text { of } \\
\text { cases }\end{array}$ \\
\hline II & 2 & XII & 2 \\
III & 3 & XIII & 1 \\
V & 12 & XIV & 1 \\
VI & 3 & XVIII & 1 \\
VIB & 1 & XIX & 1 \\
VII & 2 & XXI & 2 \\
X & 3 & XXIII & 1 \\
& 1 & Group IV & 12 \\
\hline
\end{tabular}

The only recovery in this series was made by one patient infected with Pneumococcus Type XII. It is apparent that meningitis due to Pneumococcus Type III was more frequent than that caused by any other single pneumococcal type.

In view of the almost uniformly fatal termination of this infection, it was felt that any form of treatment which held out any possible hope of

\footnotetext{
1 Fellow in Medical Sciences of the National Research Council during part of the time this study was carried out.
}

success, however remote, was worthy of trial. ${ }^{2}$ Certain observations made during a recent study on Pneumococcus Type III infection in rabbits suggested possible modes of attack upon infections with this organism in man. In this investigation $(5,6)$ it was found that those strains which produced a fatal disease in rabbits were distinguished by the capacity either to multiply or to remain viable at $41^{\circ} \mathrm{C} .\left(105.8^{\circ} \mathrm{F}\right.$.) in a medium of defibrinated rabbit's blood; while other strains, which produced merely a low-grade fluctuating bacteremia ending in recovery, in almost all instances rapidly died in vitro under the same conditions. On the basis of these facts it was suggested (6) that the normally high body temperature of the rabbit, augmented by the pyrexia induced by infection, represented an important defensive factor against those strains exhibiting a marked susceptibility to relatively slight elevations in temperature above the growth optimum of $37^{\circ} \mathrm{C}$. $\left(98.6^{\circ} \mathrm{F}\right.$.). From the results of their experiments, in some of which the temperature of rabbits likewise infected with Pneumococcus Type III was elevated by the external application of heat, Rich and McKee (7) have been led to express a similar view.

While engaged in the analysis of the immunity of rabbits to this organism, we also observed that, following vigorous and prolonged immunization with Pneumococcus Type III killed with formalin, antisera of exceptionally high titer in type-specific antibodies could be obtained in certain instances-a finding at variance with those recorded by most previous workers. Moreover, certain of our earlier unpublished experiments had suggested that the therapeutic value in mice of Antipneumococcus Type I rabbit serum was greater than that

2 A very few cases of Pneumococcus Type III meningitis treated by various procedures and in which recovery occurred, are to be found recorded in the literature (1, $2,3,4)$. 
of horse antisera of equal or greater antibody content.

On the basis of these experimental results two patients suffering from Pneumococcus Type III meningitis were treated by raising the temperature artificially by means of radiant energy applied to the surface of the body. In two other patients, rabbit serum of high specific-antibody titer mixed together with human complement, was injected intrathecally. In still another patient, both measures were employed simultaneously. ${ }^{3}$ The effect of these various procedures on the bacterial population and the fluctuations in content of soluble specific precipitable antigen, as well as free antibody when this was injected, were determined at intervals. The data thus secured form the matter of this report. Before presenting them it should, however, be stated that in no case did recovery occur. The results are recorded, therefore, because it is believed that they may be of general immunological significance, rather than with the thought of suggesting immediate further clinical trial of the methods.

\section{TECHNIQUE}

\section{Temperature regulation}

The apparatus employed to elevate the temperature of patients was simple in construction. It consisted of a box of wood ( $3 / 4$ inch thick), 33 inches high, 22 inches wide, 51 inches long, and mounted on a suitable stand $21 / 2$ feet from the floor. The long sides were equipped with apertures, about 6 inches in diameter and fitted with glass doors, which permitted manipulations of the patient without the necessity of removal from the box. Resting on the bottom of the box and supported by roller bearings was a flat stretcher-like board covered with a mattress on which the patient could be rolled in and out of the heat cabinet. The board which formed one end of the box was fixed upright to the stretcher and contained a hole large enough to permit the insertion of the patient's head. When flush with the sides of the box this movable end-piece produced a closed chamber, the temperature of which could be readily adjusted. Radiant energy was furnished by two 500-watt lamps (Champion Solinda CX-115 volt), each suitably mounted in a socket and fitted with hemispherical metal reflectors 15 inches in diameter. The edges of the latter were fitted into circular holes, 6 inches apart and 71/2 inches from either end, cut in the top of the box. The distance from the

8 The adult patient J. H. C. (vide infra) was treated at the Eye and Ear Infirmary of the Massachusetts General Hospital. The other patients were treated at the Children's Hospital, Boston. lamps to the patient's body was at least 2 feet. Circulation of air in the interior of the box was obtained with an electric fan fixed to the middle of the foot end of the box.

Continuous temperature readings were secured by means of a rectal thermocouple connected with a recording potentiometer. This record was frequently checked by an oral thermometer. The body temperature was maintained at the desired level by regulating with a thermostat, the current flowing through the lamps.

While being subjected to artificially maintained hyperpyrexia, adequate sedatives were given (barbiturates, paraldehyde) to keep the patients from excessive discomfort as evidenced by restlessness or crying. Adequate fluid intake was maintained by a continuous intravenous infusion. Because of the severity of the illness in these patients, this procedure might have been advisable under any circumstance but we considered it particularly indicated while the temperature was kept artificially elevated, to insure against the danger of excessive loss of chlorides from sweating. We realized that the dangers from cerebral edema might be increased by this procedure. Occasional analyses of the blood for chloride, serum protein, and bicarbonate were made.

\section{Antiserum}

Twelve- to sixteen-hour cultures of Pneumococcus Type III, strain SV, grown in 0.1 per cent dextrose 0.5 per cent rabbit serum infusion broth were centrifugalized at 2,800 r.p.m. for one-half hour, and the bacterial sediment taken up in an amount of 0.3 per cent formalinized physiological salt solution equivalent to one-half the volume of the discarded supernatant broth. After the suspension had stood three days at $37^{\circ} \mathrm{C}$., samples plated on blood agar gave no growth. Albino rabbits, weighing 4 to 5 pounds, were given, intravenously, 6 daily doses of 0.5 to $1.0 \mathrm{cc}$. of the vaccine thus prepared and kept in the ice box. After a rest period of 7 to 8 days, the animals were given similar successive courses of injections. Trial bleedings were taken at the end of each rest period until the type-specific agglutinin titer tested against fully capsulated organisms (such as were present in the antigen for immunization) was considered sufficiently high. Then, about $30 \mathrm{cc}$. of blood were removed by cardiac puncture. After several days another course of injections was given, followed by a bleeding for serum. In this manner, as much as 150 to $200 \mathrm{cc}$. of potent antiserum have been collected from a single animal. Before use, the serum, which had been prepared with aseptic precautions and kept without preservative at about $2^{\circ} \mathrm{C}$. in the ice box, was filtered either through a Seitz EK or Berkefeld N filter.

In attempting to use rabbits for the production of antisera against Pneumococcus Type III, it is important to immunize several animals simultaneously rather than a single animal, since there is marked variation among individuals in the response to the injection of the same dose of antigen. It is also necessary to continue the course of injections over a sufficiently long period of 
time. Thus, after two or three courses of injections the animals, in some cases, may not show a very high titer of agglutinin in the serum. If, however, they are allowed to rest a month or two and immunization begun again, it will be found that the animals respond with an increased antibody production which will then be maintained or improved on subsequent courses of injections.

The rabbit antisera employed here in the treatment of pneumococcal meningitis have in most cases shown an agglutinin titer of from 1:300 to $1: 1,000$ (final dilution of the serum). Because of depletion of the supply of high-titer antiserum, that of lesser potency has been administered on a few occasions, but it is our opinion that little or no effect on the organisms present in the spinal fluid is to be expected following the injection of less than $5 \mathrm{cc}$. of sera exhibiting a titer of less than $1: 100$.

\section{Complement}

The experiments of Robertson and Sia (8), as well as unpublished experiments carried out by one of us (J. F. E.) with H. K. Ward, have shown that the pneumococcidal action of serum containing antibody against the pneumococcus is lacking or extremely feeble in the absence of some nonspecific thermolabile component probably complement. Because of this fact and since it is well known from the data presented by Kolmer and his coworkers (9), Fothergill (10), and others, that normal spinal fluid contains no complement, and that even under conditions of meningeal irritation it is often impossible to demonstrate its presence, freshly drawn human serum, either from the patient or from a suitable donor, was mixed with the antiserum and the mixture injected intrathecally.

\section{Bacterial counts}

Measured volumes of spinal fluid or serial decimal dilutions thereof in broth were placed in Petri dishes to each of which was added about $0.5 \mathrm{cc}$. defibrinated horse blood and $10 \mathrm{cc}$. of melted infusion agar. The number of colonies developing was counted after incubation for 48 hours at $37^{\circ} \mathrm{C}$.

\section{Agglutinin titrations}

To follow the concentration of antibody present in the spinal fluid, samples were diluted in saline, equal quantities of spinal fluid dilution and antigen were mixed, incubated for 1 hour at $37^{\circ} \mathrm{C}$. and then overnight in the ice box, after which the mixtures were examined for the presence or absence of agglutination. The antigen consisted of the same formalinized saline suspension of capsulated Pneumococcus Type III organisms as used for immunization, but diluted 1:2 with saline.

\section{Precipitinogen titrations}

Fluctuations in the amount of soluble type-specific antigen in the spinal fluid were recorded by determining the highest dilution of the clear supernatant from centrifuged spinal fluid which yielded an interface ring of precipitate when layered over homologous antiserum in tubes of $2 \mathrm{~mm}$. bore. Readings were taken after two hours at room temperature (usually about $20^{\circ} \mathrm{C}$.). The same batch of antiserum was used for titrating all the samples of spinal fluid from a given case.

\section{SUMMARY OF CASES AND EXPERIMENTAL FINDINGS}

\section{Patients treated by the application of heat alone}

Case 1 ( $M c K$.). A six-year old white boy came to the hospital complaining of otitis media in the right ear, of one week's duration. As he did not present any symptoms of acute illness he was directed to return after four days' rest at home. On readmission (September 15, 1936), the child was delirious and presented signs of meningitis. Lumbar puncture was performed immediately, and the heavily capsulated gram positive cocci seen on smears of the spinal fluid were identified as Pneumococcus Type III by Neufeld and Sabin methods of typing. Intravenous saline clysis was thereupon instituted and the patient placed in the heat cabinet. The subsequent course of the infection, insofar as the immunological details are concerned, is summarized in Figure 1.

It will be seen that the application of radiant energy resulted in a rapid elevation of the patient's temperature from $103.6^{\circ} \mathrm{F}$. (on admission) to $105^{\circ} \mathrm{F}$. or over, and this was maintained for approximately 19 hours, reaching $107^{\circ} \mathrm{F}$. for some little time. Simultaneously, the number of organisms per cubic centimeter of spinal fluid fell from $225,000,000$ to 7,400 and then to 200 . The child at this time was removed from the heat cabinet and two hours later a mastoidectomy was performed, during which interval the temperature fell to $103^{\circ} \mathrm{F}$. Pus cultured from material removed at operation was sterile. After the operation the patient's temperature was again elevated artificially to above $105^{\circ} \mathrm{F}$, remaining at $106^{\circ} \mathrm{F}$. or over for seven hours. Spinal fluid culture at the end of this time showed approximately the same small number of pneumococci as on the previous culture (180 per cc.). On temporarily discontinuing the treatment, the temperature fell and the next culture yielded 9,000 organisms per cc. A subsequent $5 \frac{1}{2}$ hour period of heat treatment resulted in a temperature response which was less marked, and the number of bacteria increased (375,000 per cc.). Heat treatment was then terminated, and the patient's temperature fell to below $102^{\circ} \mathrm{F}$. The invaders then multiplied rapidly to reach in the last spinal fluid culture a figure $(67,000,000$ per cc.) approaching that of the first culture. Death followed shortly thereafter.

The amount of free soluble precipitinogen present in the spinal fluid at various times was determined by titration against Antipneumococcus Type III horse serum. The fluctuations in the quantity of this substance showed a lag in reflecting the status of the bacterial population. Thus, considerable free soluble antigen was still found at a time when the minimum in the number of bacteria had been attained; also, the minimum in soluble antigen was reached when the number of organisms had already begun to rise after remaining at a low level for some time. Even when the number of living bacteria had risen from 9,000 to 375,000 per $c c$., the precipitinogen titer did 


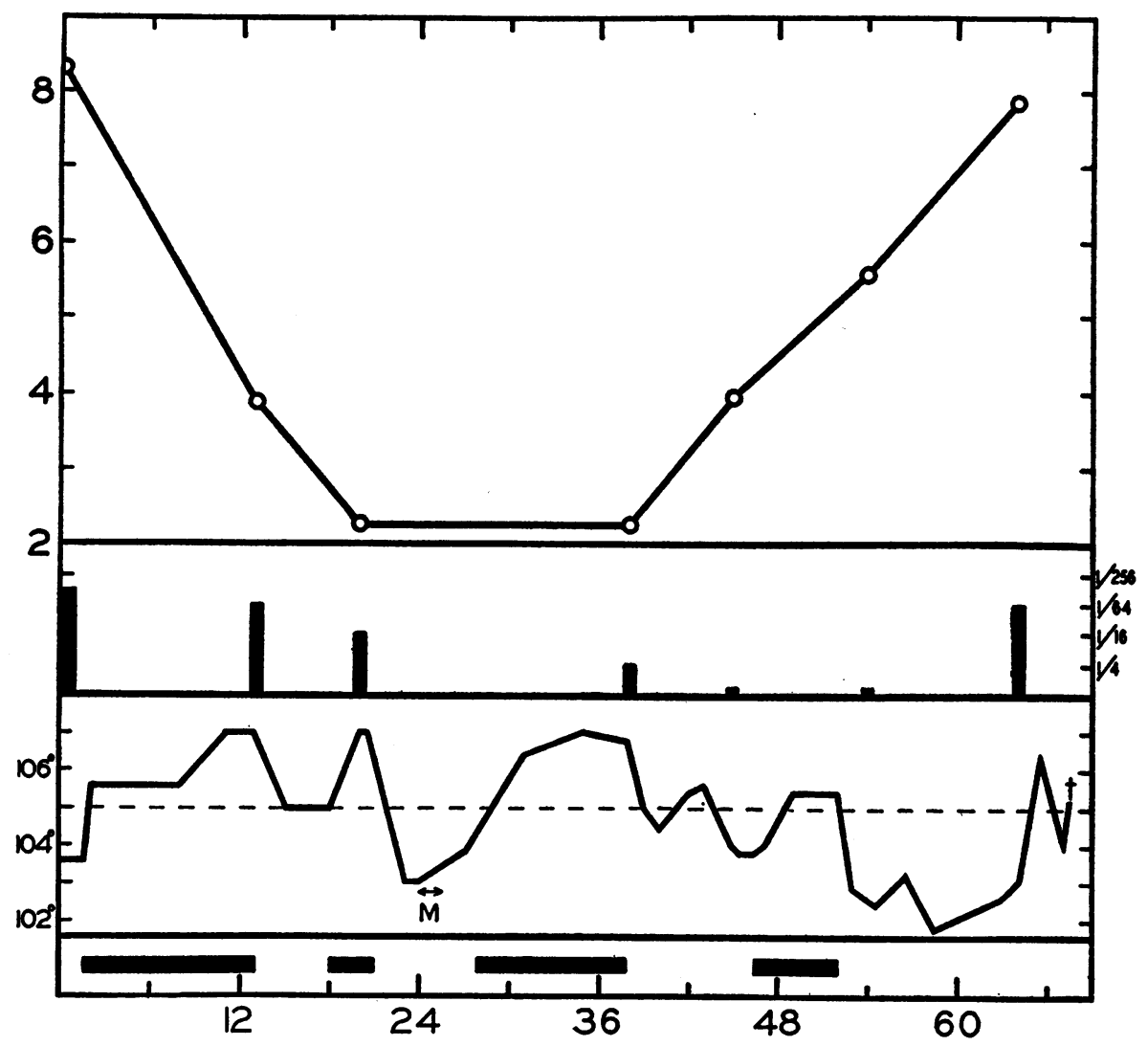

Fig. 1. CASE 1 (McK.)

Ordinates :

Upper Graph- $\log _{10}$ of number of viable Type III pneumococci per cc. of spinal fluid.

Middle Graph-Highest dilution of spinal fluid yielding definite ring in precipitinogen test against Antipneumococcus Type III horse serum.

Lower Graph-Patient's temperature in ${ }^{\circ} \mathrm{F}$. The dotted line at $105^{\circ} \mathrm{F}$. is included to emphasize the periods during which the temperature attained or surpassed this level which was regarded as the minimum to produce an effect upon the organisms.

Abscissae :

Hours. The heavy black horizontal bars indicate the periods during which radiant heat was applied to the patient's body.

$\mathrm{M}=$ Mastoidectomy.

not increase; only in the final sample of fluid containing enormous numbers of cocci was the quantity of soluble antigen again elevated.

These findings are of interest since they give some indication of the rate at which the soluble specific substancè, distinguished as it is by a rather large molecule, is removed from the subarachnoid spaces. It is evident that within 36 hours about 97 per cent of the quantity present in the first sample of cerebrospinal fluid has disappeared; by 44 hours only 0.8 per cent remains.

The susceptibility to heat of the strain infecting this patient was determined in vitro by plating samples taken at intervals from cultures in defibrinated rabbit's blood, kept at $37^{\circ}$ and $41^{\circ} \mathrm{C}$., respectively. It was found that this strain fell into the intermediate group which has been described previously (6). The number of viable cocci at $41^{\circ} \mathrm{C}$. never approached that of the culture at $37^{\circ} \mathrm{C}$, but the total numbers at $41^{\circ} \mathrm{C}$. exhibited a very slight increase at the end of 24 hours. In the patient, however, the elevation of temperature to at least $105^{\circ} \mathrm{F}$., the level which we have considered desirable, appeared to be spectacularly effective in reducing the numbers of pneumococci. This was probably obtained not only by the direct bactericidal action but also by a bacteriostatic effect which seemed to permit the phagocytes in the spinal fluid to attack the impaired cocci, since 


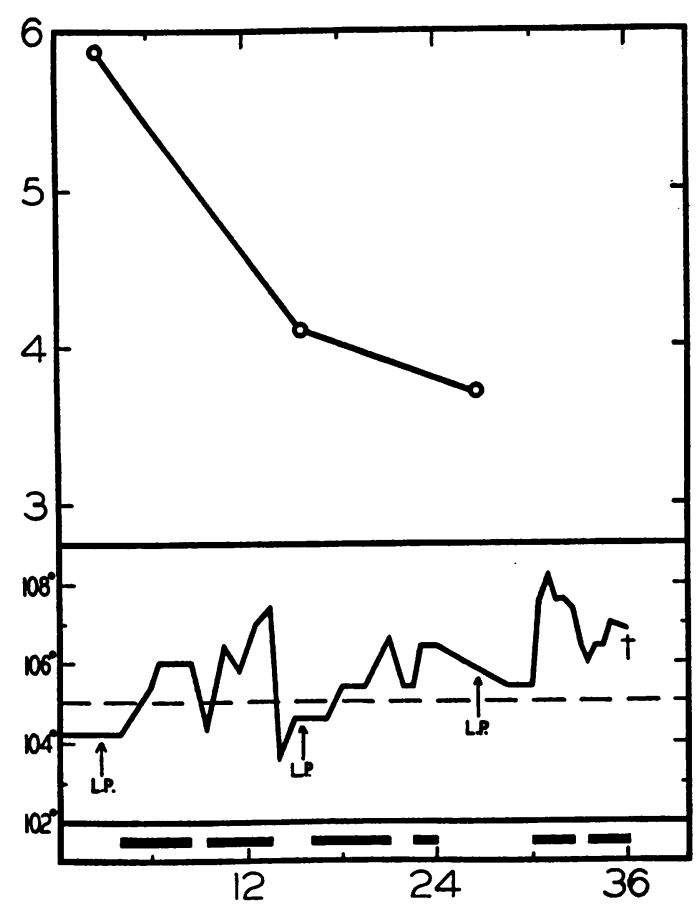

FIG. 2. CASE 2 (KI.)

Ordinates :

Upper Graph-Log $\operatorname{Lof}_{10}$ number of viable Type III pneumococci per cc. of spinal fluid.

Lower Graph-Patient's temperature in ${ }^{\circ} \mathrm{F}$. Abscissae:

Hours. Heavy black horizontal bars indicate the periods during which radiant heat was applied to the patient's body.

L.P. = Lumbar puncture.

the examination of smears following heat treatment showed marked phagocytosis which was absent in the beginning.

Case 2 (Ki.). A five-year old white boy developed symptoms of meningeal infection a month after signs of left otitis media had first appeared and the latter condition had apparently subsided. On admission (October 25, 1936), after $x$-ray plates had been taken and examined, mastoidectomy was performed, but the infection appeared to be on the wane and culture from the site of operation gave no growth. For three days the child's condition improved; although the temperature had remained at $103^{\circ} \mathrm{F}$. for a day following the operation, it then returned to normal. On the evening of the fourth day, however, the signs of irritability and stiffness of the neck became more pronounced. A culture of the spinal fluid on the following day, was found to contain Type III pneumococci. On October 30, the administration of fluid by constant intravenous drip was instituted and the boy placed in the heat cabinet. Data secured by studies on samples of the cerebrospinal fluid and the course of the temperature are summarized in Figure 2.
The number of pneumococci per cc. of spinal fluid, shortly before fever therapy was begun, was 750,000 . With the aid of the heat cabinet, the temperature was elevated to approximately $106^{\circ} \mathrm{F}$. and maintained at this level over a period of nine hours, except for a short interval. The number of bacteria fell to 12,000 per cc. A second period of treatment for $61 / 2$ hours maintained the temperature at $105^{\circ} \mathrm{F}$. or over, and the bacterial population further diminished to 5,000 per cc. After this last lumbar puncture, $7.5 \mathrm{cc}$. of Antipneumococcus Type III rabbit serum (agglutinin titer 1:400) together with $14 \mathrm{cc}$. of fresh human serum (containing complement) from a donor who had recovered from Pneumococcus Type III pneumonia two years previously, were introduced into the spinal canal. With this was combined a further session of fever treatment. The temperature rose rapidly to reach $108.2^{\circ} \mathrm{F}$., then fell to $106^{\circ} \mathrm{F}$, but the child died 10 hours after the last lumbar puncture. Since death followed so soon, no further data were obtained. We have therefore included this case among those treated with heat alone since the effect of antiserum was not determined.

At autopsy, aside from the infection of the meninges, mastoid cells, labyrinth, and left petrous bone, there was found a brain abscess and a thick greenish-gray, cloudy exudate bathing the cranial nerves and base of the brain, particularly around the optic chiasm and foramen of Luschka. There appeared to be a connecting link between the otitis media, mastoiditis, and direct extension to the meninges. A culture from the right hemisphere yielded Pneumococcus Type III, but that from the base of the brain was sterile.

In vitro heat susceptibility test of the strain isolated from the first spinal fluid culture before fever treatment was begun showed this organism like that of the previous case to belong to the intermediate group of strains not markedly susceptible in defibrinated rabbit's blood to a temperature of $41^{\circ} \mathrm{C}$. But here again fever treatment of the patient markedly lowered the bacterial population of the spinal fluid.

\section{Patients treated by the injection of Antipneumococcus Type III rabbit serum}

Case 3 (J. H. C.). A white male, twenty-nine years old, was admitted (August 22, 1934) to the Massachusetts Eye and Ear Infirmary with the diagnosis of acute right mastoiditis and meningitis. Radical mastoidectomy was performed. The same evening a lumbar puncture yielded spinal fluid containing Pneumococcus Type III. It was decided to attempt treatment with the aid of typespecific antipneumococcus rabbit serum, furnished by one of us (J. F. E.).

The results are summarized in Figure 3. A single dose of $2.5 \mathrm{cc}$. of Antipneumococcus Type III rabbit serum (agglutinin titer $1: 1,000$ ) plus $8 \mathrm{cc}$. of human serum complement resulted in temporary sterilization of the spinal fluid, which had contained approximately $15,000,000$ pneumococci per cc. At the same time, the free 


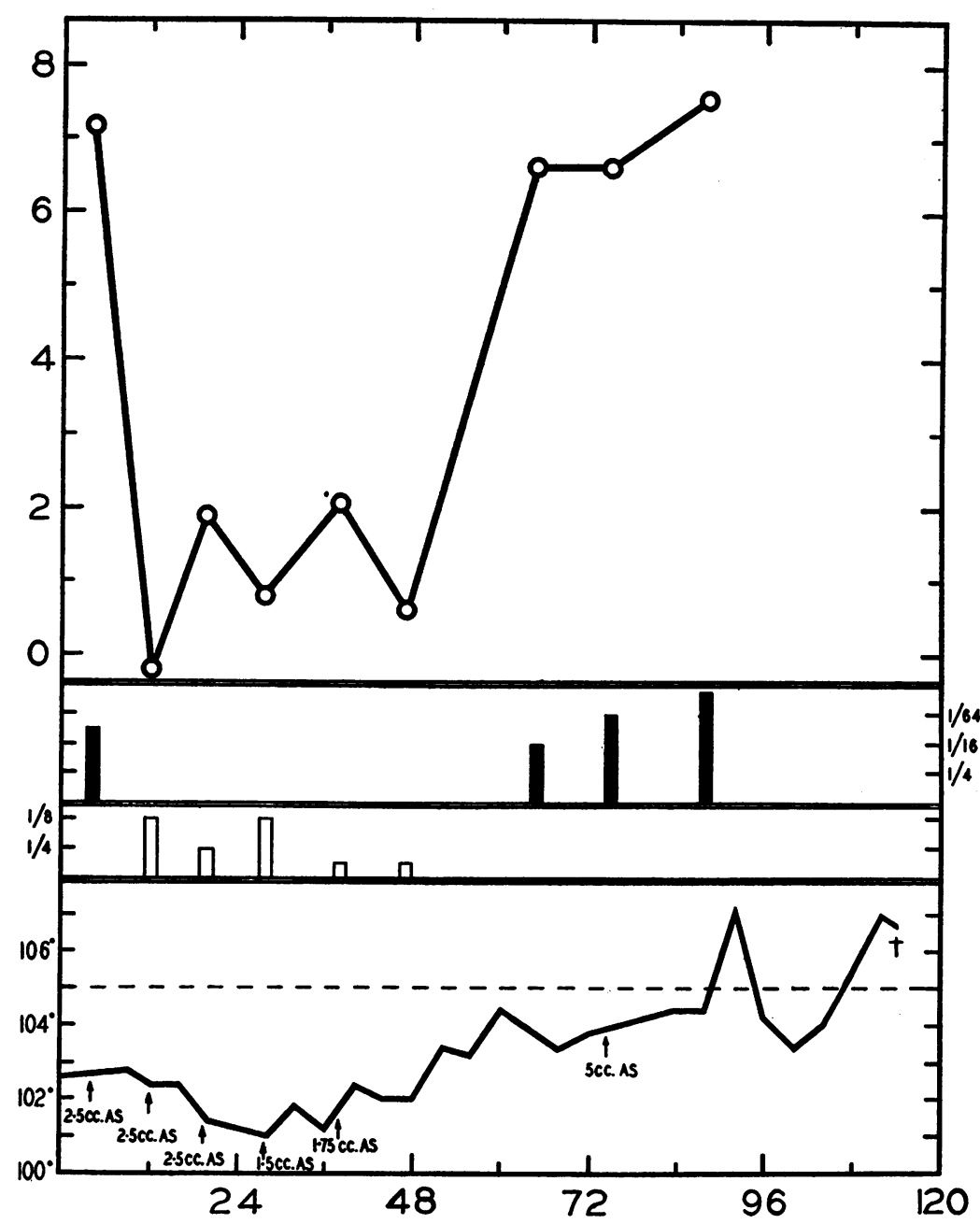

Fig. 3. Case 3 (J. H. C.)

Ordinates:

Uppermost Graph- $\log _{10}$ of number of viable Type III pneumococci per cc. of spinal fluid.

Upper Middle Graph-Highest dilution of spinal fluid yielding definite ring in precipitinogen test against antipneumococcus Type III horse serum.

Lower Middle Graph-Highest dilution of spinal fluid causing agglutination of a formalinized saline suspension of encapsulated Type III pneumococci.

Lowermost Graph-Patient's temperature in ${ }^{\circ} \mathrm{F}$. The arrows indicate times at which the stated amounts of Antipneumococcus Type III rabbit serum (AS) mixed with fresh human serum as complement, were adAbscissae: Hours. ministered intrathecally.

soluble type-specific precipitinogen, which had been present in the first fluid withdrawn to a dilution of $1: 32$, disappeared while free agglutinins (titer $1: 8$ ) were demonstrable. Successive administrations of similar doses of antiserum and complement held the bacterial count over the next 36 hours at a low level, fluctuating between 4 and 125 per cc., while free soluble precipitinogen was not demonstrable. On the 7th lumbar puncture no antiserum was injected and in the 8th sample of fluid (taken some 181/2 hours later) the organisms had risen to $4,300,000$, while free soluble antigen was again present and the agglutinins had gone. The last injection of antiserum, given after the next lumbar puncture, failed to have any demonstrable effect on the bacterial population. 
This may well be attributable to its lower antibody titer and the very large amount of free type-specific antigen in the fluid at this time, which would greatly diminish the amount of antibody available for sensitization of the organisms.

The temperature of the patient remained well below $105^{\circ} \mathrm{F}$. throughout the course of treatment until just day the culture of spinal fluid yielded a growth of Pneumococcus Type III. It was, therefore, decided to employ type-specific rabbit antiserum as a therapeutic measure. Figure 4 summarizes the pertinent findings.

Following lumbar puncture and withdrawal of spinal fluid for determination of the number of pneumococci (33,000 per cc.), 4 cc. of Antipneumococcus Type III

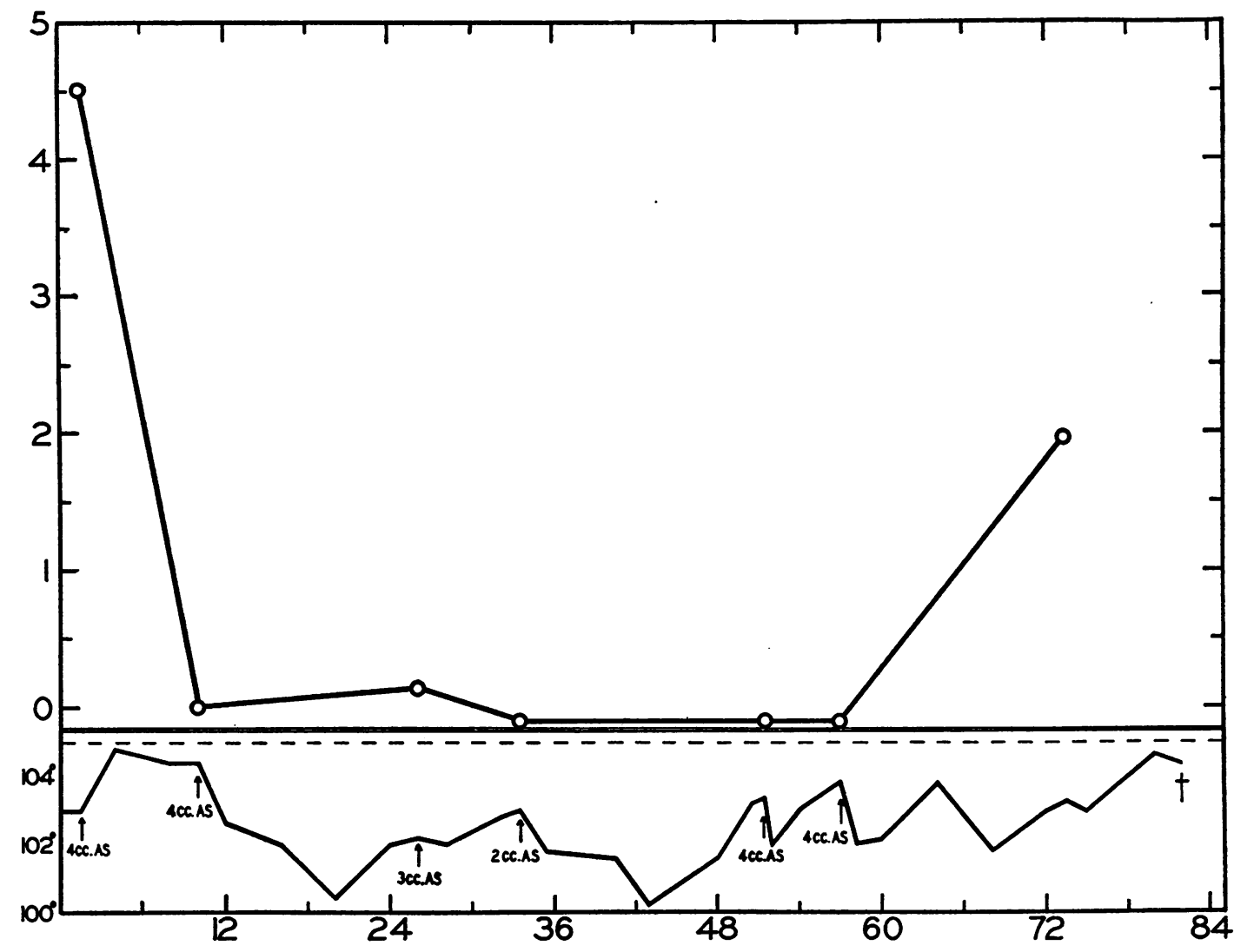

Fig. 4. CASE 4 (C. T.)

Ordinates :

Upper Graph-Log 10 of number of viable Type III pneumococci per cc. of spinal fluid.

Lower Graph-Patient's temperature in ${ }^{\circ} \mathrm{F}$. The arrows indicate times at which the stated amounts of Antipneumococcus Type III rabbit serum (AS), mixed with fresh human serum as complement, were administered intrathecally.

Abscissae: Hours.

before death, and no adjuvant effect of fever could therefore be expected to aid in the destruction of the organism which had been shown by in vitro tests (recorded elsewhere (6) as Strain IE) to be relatively resistant to temperatures up to $106^{\circ} \mathrm{F}$.

Case 4 (C. T.). A twelve-year old white girl was admitted to the private ward of the Children's Hospital, February 16, 1936, with rigidity of the neck and a history of middle-ear infection of two weeks' duration. After roentgenogram and lumbar puncture (for culture), left mastoidectomy was performed and following this the patient spent a fairly comfortable evening. By the next rabbit serum (agglutinin titer $=1: 1,000$ ) plus $8 \mathrm{cc}$. of the patient's own serum as complement were administered intrathecally. This resulted in temporary sterilization of the spinal fluid; three subsequent injections of 2 to 4 cc. of this same antiserum followed by one injection of $4 \mathrm{cc}$. of serum of a lower agglutinating titer $(1: 128)$, together with $8 \mathrm{cc}$. of complement each time, kept the spinal fluid sterile or with not more than 1 or 2 organisms per cc. for a period of 47 hours. The agglutinin titer of the spinal fluid never exceeded 1:2 and fell after the fourth injection of serum to $1: 1$. On lumbar puncture $161 / 2$ hours after the sixth and last dose of antiserum- 


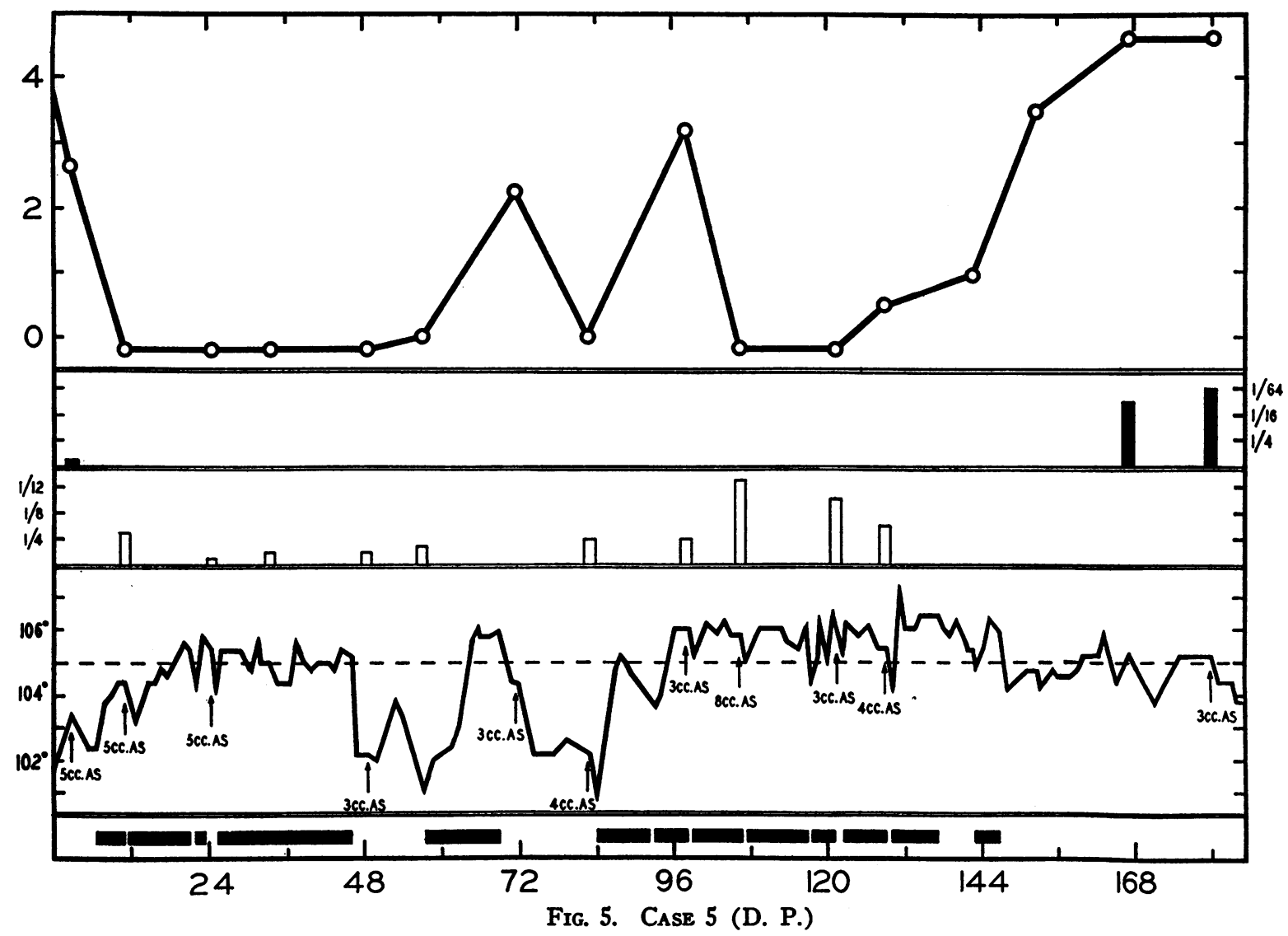

Ordinates :

Uppermost Graph- $\log _{10}$ of number of viable Type III pneumococci per cc. of spinal fluid.

Upper Middle Graph-Highest dilution of spinal fluid yielding definite ring in precipitinogen test against Antipneumococcus Type III horse serum.

Lower Middle Graph-Highest dilution of spinal fluid causing agglutination of a formalinized saline suspension of encapsulated Type III pneumococci.

Lowermost Graph-Patient's temperature in ${ }^{\circ} \mathrm{F}$. The arrows indicate times at which the stated amounts of Antipneumococcus Type III rabbit serum (AS), mixed with fresh human serum as complement, were administered intrathecally.

Abscissae :

Hours. The heavy black horizontal bars indicate the periods during which radiant heat was applied to the patient's body.

complement mixture, no agglutinins were found in the spinal fluid and the number of pneumococci per cc. was 92. The patient died $81 / 2$ hours later; permission for autopsy was not obtained.

The patient's temperature never rose above $104.8^{\circ} \mathrm{F}$. during the entire period of hospitalization; the strain of pneumococci from the cerebrospinal fluid was found by in vitro test (see (6), Table I, Strain Tirrell) to belong to the intermediate group of relatively resistant organisms which were not killed off within 24 hours at $41^{\circ} \mathrm{C}$.

\section{Patient treated with type-specific antiserum and the application of heat}

Case 5 (D. P.). A white boy five years and eight months of age, was admitted to the Children's Hospital on November 22, 1936, with history of pain in the back of the neck and repeated vomiting during the previous 24 hours, following a middle-ear infection of two weeks' duration. Roentgenogram showed diffuse clouding of the left mastoid but without apparent destruction. Lumbar puncture was performed and since no organisms were seen on direct smear of the cloudy spinal fluid, $15 \mathrm{cc}$. of antimeningococcus horse serum were given intrathecally. Smears made later the same day from the cultures of cerebrospinal fluid revealed gram positive cocci. Several doses of prontosil were administered per os and intramuscularly. By the following day the organism was identified as Pneumococcus Type III. Since no definite result had been obtained by the measures previously employed, intrathecal treatment with Antipneumococcus Type III 
rabbit serum plus fresh human serum complement was begun, together with heat treatment and constant intravenous saline clysis. On the second afternoon, mastoidectomy was performed; the left mastoid was found to be largely destroyed, with infection extending down to the dura.

The results of combined antiserum and hyperpyrexia treatment are shown on Figure 5. Following the application of these measures, sterility of the spinal fluid and disappearance of soluble precipitinogen rapidly resulted and this condition was maintained for over 36 hours. During this period agglutinins were demonstrable in the fluid, cerebrospinal fluid sugar returned to normal (this was the first case in which this had been observed), and there was a slight decrease in the number of cells in the cerebrospinal fluid. In the following 22 -hour interval, when antiserum was not given, agglutinins and sugar disappeared from the cerebrospinal fluid, while pneumococci reappeared. Simultaneously, the clinical condition of the patient became worse and never improved afterwards.

The two batches of antiserum previously injected had shown agglutinin titers of $1: 600$ and $1: 1,000$ respectively. Another $3 \mathrm{cc}$. dose of antiserum (titer $1: 1,000$ ) plus 8 cc. human complement again reduced the number of organisms to one per cc., even though the patient's temperature fell far below $105^{\circ} \mathrm{F}$. Four cc. of antiserum (titer $1: 400$ ) plus $4 \mathrm{cc}$. complement were injected on the following lumbar puncture while fever therapy was resumed; however, the next sample of spinal fluid withdrawn showed not only agglutinins but 1,500 pneumococci per cc. as well. These organisms on smear exhibited peculiarly stained swollen capsules, as though a brokendown lesion somewhere had discharged them shortly before into the spinal fluid, where under the influence of the antiserum they underwent "Quellung." Furthermore, many of them were to be seen within phagocytes -up to 9 in a single cell. Two successive subsequent administrations of antiserum (titer $1: 400$ ) plus complement, together with fever treatment to maintain temperature above $105^{\circ} \mathrm{F}$, again resulted in spinal fluid which was sterile and free from soluble antigen, over a 15-hour period. Owing to the temporary exhaustion of the supply of sera of high titer, a batch of serum of less value (titer $1: 160$ ) was employed for the next two treatments. A few pneumococci were found-3 and 9 per cc. respectively-in the fluid of the two following lumbar punctures. With the temporary discontinuance of antiserum treatment and fever therapy (except for 31/2 hours at a temperature above $105^{\circ} \mathrm{F}$.), the bacterial count rose to 3,200 per $\mathrm{cc}$. and then to 42,000 per $\mathrm{cc}$., and remained at this level although the temperature fluctuated between 104 and $106^{\circ} \mathrm{F}$. for much of the time, without the application of external heat. The patient had become completely comatose, with marked edema of the face and extremities, and râles in both lungs. Uncombined antibodies were no longer to be detected and soluble antigen which had not been demonstrable since the first injection of antiserum reappeared in considerable and increasing amount. Twenty-four hours after the last injection of antiserum recorded on the figure, the patient's temperature began to rise rapidly, reached $106^{\circ} \mathrm{F}$. and within six hours the patient was dead.

The autopsy findings were:-tracheobronchitis, bronchopneumonia and transudative phenomena indicative of right heart failure, as well as otitis media, dural sinus thrombosis, and cerebrospinal meningitis. A probably important factor in the causation of death was internal hydrocephalus, apparently due to obstruction of the foramina of Luschka and Magendie occasioned by the presence of thick yellow exudate (containing Pneumococcus Type III) which was found covering the base of the brain and also in smaller amounts over the convex surface along the sulci.

In vitro test of the thermal properties of the strain of pneumococcus isolated from this patient showed it to be somewhat susceptible to a temperature of $41^{\circ} \mathrm{C}$., as the numbers of viable cocci per cubic centimeter of defibrinated rabbit's blood kept at this temperature, diminished with passage of time, although complete sterility was not obtained even after 25 hours' incubation.

\section{DISCUSSION}

During recent years there has taken place a renaissance of interest in the immunological rôle of fever and its possible application as a factor of importance in the therapy of certain infections (e.g., conditions caused by Treponema pallidum (11 to 16$)$, gonococcus (17 to 23 ), tubercle bacillus $(24,25)$, meningococcus $(26,27,28)$; virus diseases of plants $(29,30)$; also, bactericidal substances occurring in the serum during fever $(31,32,33))$. Insofar as we are aware, however, no direct attempts have previously been made to apply to human cases the experimental results which suggest the favorable effect of high body temperatures upon Pneumococcus Type III infections in animals $(5,6,7)$. In the foregoing sections, the procedure of artificially raising the body temperature above that usually obtaining during Type III pneumococcus meningitis has been shown to result in a striking diminution in the number of organisms inhabiting the spinal fluid. Although by in vitro test in defibrinated rabbits' blood the particular strains infecting certain of these patients were found to be moderately resistant to the temperatures which they encountered in the human body during the periods of hyperpyrexia, previous work has shown that other strains die out rapidly at this same temperature $\left(40.5\right.$ to $41^{\circ} \mathrm{C}$.). More satisfactory results might well attend fever treatment in the case of patients 
infected with such markedly thermo-susceptible organisms. The data which have been secured, nevertheless, indicate clearly that raising the body temperature above $105^{\circ} \mathrm{F}$. and maintaining it at that level for a number of hours checks the multiplication even of organisms somewhat resistant to heat and leads to destruction of the major portion, possibly by rendering them susceptible to phagocytosis. Although the fever treatment to which these patients were subjected has not been sufficient to clear the spinal fluid entirely of invading bacteria, the results in humans may be considered in general to confirm and extend those derived from the experiments in vitro and in rabbits which have been reported previously (5, $6,7)$.

Until lately the only sera which were considered to be at all effective in the therapy of pneumococcus infection were those directed against Types I and II. Due in large measure to the classification of pneumococci belonging to Group IV into a number of distinct types, evidence has been presented that antisera against certain of these, Types V, VII and VIII for example, are also of value ( 34 to 37 ). But at the present time the consensus is that Antipneumococcus Type III sera exert little or no influence upon disease caused by the homologous organism $(38,39)$. The disappointing results of various clinical trials are perhaps to be expected in view of the failure of most workers to produce sera containing adequate quantities of antibody. Such early investigators as Hanes (40), Cole (41) and Adler (42) failed to find in Antipneumococcus Type III sera which they prepared, any protective power, or in most cases antibody demonstrable by in vitro tests. Wadsworth and Kirkbride (43) produced antisera in horses which would not agglutinate the capsulated organisms in dilutions higher than $1: 40$, but which they felt possessed slight protective power for mice. We have since received samples of horse antisera from the New York City and New York State Departments of Health which contained relatively large amounts of precipitins and agglutinins and were able to bring about the sterilization of the blood stream in rabbits with Pneumococcus Type III bacteremia. Yoshioka (44) obtained protection in mice and agglutinin titers up to $1: 200$ with anti- sera prepared in rabbits. On the other hand, Tillett (45) in 28 immunized rabbits was able to detect type specific antibodies in only four (agglutinins and mouse protective antibodies), and the strongest serum agglutinated the homologous organism in dilutions not exceeding $1: 20$. More recently, however, Watson and Cooper (46) reported that they were able to protect rabbits against fatal doses of Pneumococcus Type III by means of a concentrated horse antiserum, and Platt (47) in certain studies on the complement fixation reaction employed an Antipneumococcus Type III rabbit serum exhibiting an agglutinin titer of $1: 400$.

In a previous communication we have described the production in rabbits of high-titer type-specific agglutinating serum following prolonged immunization with formalinized Type III pneumococci and have demonstrated considerable mouse protective effect in certain of these sera (48). Experiments by Dr. I. Ardelean, using the bactericidal technique employed in this laboratory (49), have also shown that in vitro these sera possess marked opsonizing properties versus young, fully encapsulated organisms. Unpublished experiments carried out several years ago by one of us (J. F. E.) had indicated that, in mice, 16 hours after establishment of an infection the therapeutic effect of Antipneumococcus Type I rabbit sera was superior to that of Antipneumococcus Type I horse sera which by various tests (agglutination, precipitation, effect in the bactericidal system, and mouse protective power) were shown to contain equivalent or greater quantities of antibodies. Because of these observations, in 1934, in our first attempt at antiserum treatment in Pneumococcus Type III meningitis (Case 3, this paper), we employed rabbit sera. Recently, Horsfall, Goodner and MacLeod (50) have summarized experimental results which demonstrate and elucidate the apparent therapeutic superiority of Antipneumococcus Type I rabbit antiserum compared with that prepared in the horse. Our observations, as far as they extend, support their conclusions.

Although limited to only two cases, the results presented above show that in Pneumococcus Type III meningitis relatively small quantities of hightiter rabbit antiserum bring about the destruction 
of the very large numbers of cocci which may be present in the cerebrospinal fluid. In addition, the serum neutralizes considerable amounts of the specific soluble substance. We are convinced that such antisera are efficient antibacterial agents against those organisms to which they have access in the company of active phagocytes. One of the obstacles to complete success in this regard is the existence of localized or walled-off areas of inflammatory exudate which appear frequently to present an impassable barrier. Connected with this are the deleterious effects of impaired circulation of the cerebrospinal fluid and various pathological conditions of serious consequence secondary to the presence of these lesions. In all likelihood these circumstances, so unfortunate from the standpoint of the recovery of the patient, are often due in large measure to the relatively chronic or prolonged course of the infection before hospitalization. In our opinion, success of antiserum therapy in this disease will be determined largely on the inauguration of treatment previous to the localization of infection.

\section{SUMMARY}

1. The effect of elevating the body temperature to $105^{\circ} \mathrm{F}$. or higher for periods of several hours on the bacterial infection of the spinal fluid, has been determined in two patients with Type III pneumococcus meningitis. Under these conditions there occurred a marked reduction in the number of viable pneumococci and the quantity of free soluble type-specific antigen present. In neither case was sterility of the fluid attained.

2. In two patients the effect of treatment by the intrathecal injection of potent Antipneumococcus Type III rabbit serum was analyzed. Temporary sterility of the spinal fluid followed rapidly in each case, concommitantly with the disappearance of soluble antigen. Eventually, however, the pneumococci reappeared. The causes of failure to obtain the permanent sterilization of the subarachnoid space are discussed.

3. The combined treatment, consisting of artificial fever through the application of radiant heat and injection of rabbit antiserum, appeared to produce the best result as estimated by the conditions obtaining in the cerebrospinal fluid, although here again recovery of the single patient so treated did not ensue.
4. The capacity of Antipneumococcus Type III rabbit serum of high antibody titer to mediate the destruction in the cerebrospinal fluid of man of the homologous organisms which are accessible to its sensitizing action seems clearly demonstrated.

\section{BIBLIOGRAPHY}

1. Ratnoff, H. L., and Litvak, A. M., Pneumococcus meningitis treated with Morgenroth's optochin hydrochloride. Report of a case with recovery. Arch. Pediat., 1926, 43, 466.

2. Weinberg, M. H., Case of pneumococcus (Type III) meningitis treated with potassium permanganaterecovery. A plea for its trial. J. Nerv. and Ment. Dis., 1931, 74, 38.

3. Steinholz, R., and Gleich, M., Pneumococcus (Type III) meningitis; recovery. J. A. M. A., 1935, 105, 795.

4. Tripoli, C. J., Bacterial meningitis. A comparative study of various therapeutic measures. J. A. M. A., 1936, 106, 171.

5. Enders, J. F., and Shaffer, M. F., An analysis of certain factors in the virulence for rabbits of pneumococcus Type III. J. Immunol. (Proc.), 1936, 30, 382.

6. Enders, J. F., and Shaffer, M. F., Studies on natural immunity to pneumococcus Type III. I. The capacity of strains of pneumococcus Type III to grow at $41^{\circ} \mathrm{C}$. and their virulence for rabbits. J. Exper. Med., 1936, 64, 7.

7. Rich, A. R., and McKee, C. M., The mechanism of a hitherto unexplained form of native immunity to the Type III pneumococcus. Bull. Johns Hopkins Hosp., 1936, 59, 171.

8. Robertson, O. H., and Sia, R. H. P., Studies on pneumococcus growth inhibition. VII. The relation of opsonins to natural resistance against pneumococcus infection. J. Exper. Med., 1927, 46, 239.

9. Kolmer, J. A., Toyama, I., and Matsunami, T., The influence of active normal serum (complement) upon meningococci. I. The opsonic activity of fresh normal serum alone and in combination with antimeningitis serum for meningococci. J. Immunol., 1918, 3, 157.

10. Fothergill, L. D., Observations on the presence of complement in the cerebrospinal fluid in various pathologic conditions of the central nervous system. J. Pediat., 1935, 6, 374.

11. v. Wagner-Jauregg, J., Uber die Einwirkung der Malaria auf die progressive Paralyse. Psychiat.neurol. Wchnschr., 1918, 20, 132.

12. Boak, R. A., Carpenter, C. M., and Warren, S. L., Studies on the physiological effects of fever temperatures. III. The thermal death time of Treponema pallidum in vitro with special reference to fever temperatures. J. Exper. Med., 1932, 56, 741. 
13. Carpenter, C. M., Boak, R. A., and Warren, S. L., Studies on the physiological effects of fever temperatures. IV. The healing of experimental syphilis lesions in rabbits by short wave fevers. J. Exper. Med., 1932, 56, 751.

14. Simpson, W. M., Artificial fever therapy of syphilis. J. A. M. A., 1935, 105, 2132.

15. Neymann, C. A., Lawless, T. K., and Osborne, S. L., The treatment of early syphilis with electropyrexia. J. A. M. A., 1936, 107, 194.

16. Culler, A. M., and Simpson, W. M., Artificial fever therapy in cases of ocular syphilis. Arch. Ophth., 1936, 15, 624.

17. Warren, S. L., and Wilson, K. M., The treatment of gonococcal infections by artificial (general) hyperthermia. A preliminary report. Am. J. Obst. and Gynec., 1932, 24, 592.

18. Carpenter, C. M., Boak, R. A., Mucci, L. A., and Warren, S. L., Studies on the physiologic effects of fever temperatures. The thermal death time of Neisseria gonorrheae in vitro with special reference to fever temperatures. J. Lab. and Clin. Med., 1933, 18, 981.

19. Desjardins, A. U., Stuhler, L. G., and Popp, W. C., Fever therapy for gonococcic infections. I and II. J. A. M. A., 1935, 104, 873. Ibid., 1936, 106, 690.

20. Hench, P. S., Slocumb, C. H., and Popp, W. C., Fever therapy: results for gonorrheal arthritis, chronic infectious (atrophic) arthritis, and other forms of "rheumatism." J. A. M. A., 1935, 104, 1779.

21. Bierman, W., and Horowitz, E. A., Treatment of gonorrhea in the female by means of systemic and additional pelvic heating. J. A. M. A., 1935, 104, 1797.

22. Simpson, W. M., Artificial fever therapy of syphilis and gonococcic infections. New York State J. Med., 1936, 36, 1290.

23. Humiston, H. W., The use of heat and fever in the treatment of gonococcus infections. Am. J. Syph., Gonor. and Ven. Dis., 1937, 21, 554.

24. Duncan, G. R., Fenger, E. P. K., and Greene, A. B., The treatment of pulmonary tuberculosis by hyperpyrexia. A preliminary report. Am. Rev. Tuberc., 1933, 28, 752.

25. Duncan, G. R., and Mariette, E. S., The treatment of pulmonary tuberculosis by hyperpyrexia. 3 . Temperatures that inhibit growth of cultures of mammalian and avian tubercle bacilli and one strain of leprae bacillus. A method of typing suggested. Am. Rev. Tuberc., 1935, 31, 687.

26. Bennett, A. E., Person, J. P., and Simmons, E. E., Treatment of chronic meningococcic infections by artificial fever. Arch. Phys. Therap., 1936, 17, 743.

27. Platou, E. S., McElmeel, E., and Stoesser, A., Artificial fever in the treatment of meningococcus infection. Minnesota Med., 1936, 19, 781.

28. Moench, L. M., A study of the heat sensitivity of the meningococcus in vitro within the range of thera- peutic temperatures. J. Lab. and Clin. Med., 1937, 22, 665 .

29. Kunkel, L. O., Heat treatments for the cure of yellows and other virus diseases of peach. Phytopath., 1936, 26, 809.

30. Kunkel, L. O., Effect of heat on ability of Cicadula sexnotata (Fall.) to transmit Aster yellows. Am. J. Bot., 1937, 24, 316.

31. Wulff, F., On thermostable bactericidal substance demonstrated in human serum, particularly during fever. J. Immunol., 1934, 27, 451.

32. Tillett, W. S., The bactericidal action of human serum on hemolytic streptococci. I. Observations made with serum from patients with acute infections and from normal individuals. J. Exper. Med., 1937, $65,147$.

33. Hjorth, P., En oversigt over de baktericide stoffer i normalt blod specielt hos mennesket. Samt unders $\phi$ gelser over en termostabil bakteridraebende substans, saertigt forekommende i feber patienters serum. Ugesk. f. laeger, 1937, 99, 192.

34. Bullowa, J. G. M., The therapeutic value of specific Type VII (Cooper) antipneumococcic serum. Libman Anniv. Vols., 1932, 1, 283.

35. Bullowa, J. G. M., Therapeutic pneumococcus Type VIII (Cooper) serum. J. A. M. A., 1934, 102, 1560.

36. Finland, M., and Tilghman, R. C., Clinical and immunologic observations in cases of pneumococcus Type $V$ pneumonia treated with specific antibody. New England J. Med., 1936, 215, 1211.

37. Finland, M., Tilghman, R. C., Ruegsegger, J. M., and Dowling, H. F., Clinical and immunological observations in cases of pneumococcus Type VII pneumonia treated with concentrated type-specific antibody. Am. J. M. Sc., 1937, 193, 59.

38. Cecil, R. L., Plummer, N., and McCall, M., Pneumococcus Type III in pneumonia. An analysis of 500 cases. Am. J. M. Sc., 1936, 191, 305.

39. Lord, F. T., and Heffron, R., Lobar Pneumonia and Serum Therapy. Commonwealth Fund, N. Y., 1936 , p. 27.

40. Hanes, F. M., An immunological study of Pneumococcus mucosus. J. Exper. Med., 1914, 19, 38.

41. Cole, R., Pneumococcus infection and immunity. New York Med. J., 1915, 101, 59.

42. Adler, $H$., Uber Pneumokokkentypen und Pneumokokkenimmunität. Ztschr. f. Hyg. u. Infektionskr., 1923, 101, 140.

43. Wadsworth, A. B., and Kirkbride, M. B., A note on the production of antipneumococcus sera. J. Exper. Med., 1917, 25, 629.

44. Yoshioka, M., Beiträge zur Pneumokokkenimmunität. IV. Uber die Gewinnung von Antipneumo- und Antistreptokokkenserum von Kaninchen. Ztschr. f. Hyg. u. Infektionskr., 1923, 97, 408.

45. Tillett, W. S., Studies on immunity to Pneumococcus 
mucosus (Type III). I. Antibody response of rabbits immunized with Type III pneumococcus. J. Exper. Med., 1927, 45, 713.

46. Watson, E. L., and Cooper, G., The production of infection with pneumococci in rabbits by intradermal inoculation of Type III pneumococci, the treatment with antiserum, and a comparison with Type I infections. J. Exper. Med., 1930, 52, 849.

47. Platt, A. E., The relationship of the complement fixation optimum to the agglutination optimum. Australian J. Exper. Biol. and M. Sc., 1936, 14, 101.
48. Enders, J. F., and Shaffer, M. F., Behavior exhibited by mixtures of pneumococcus Type III and homologous antiserum, analogous to that described for similar associations of virus and antiviral serum. J. Immunol., 1937, 32, 379.

49. Enders, J. F., and Wu, C. J., An immunological study of the A substance or acetyl polysaccharide of pneumococcus Type I. J. Exper. Med., 1934, 60, 127.

50. Horsfall, F. L., Jr., Goodner, K., and MacLeod, C. M., Type specific antipneumococcus rabbit serum. Science, 1936, 84, 579. 